\title{
Synaptic activity and excitability modulates information transfer in Purkinje cells: a modeling study
}

\author{
Allan D Coop ${ }^{2}$, Hugo Cornelis ${ }^{2}$, Fidel Santamaria ${ }^{1 *}$ \\ From Nineteenth Annual Computational Neuroscience Meeting: CNS*2010 \\ San Antonio, TX, USA. 24-30 July 2010
}

Dendritic excitability is the consequence of the different concentration and distribution of active conductances. The excitability of the cell could be a mechanism for storing memories and is affected by development and experience. Information in Purkinje cells (PCs) flows from dendrites to soma without the influence of backpropagating action potentials. Thus, PCs are ideal to quantify the incremental contribution of dendritic channels to information processing.

We used a previously published PC model $[1,2]$. The model was stimulated with several combinations of excitatory and inhibitory rates of synaptic activity $\left(E I_{r}\right)$. Since our objective was to quantify information processing in dendrites we chose $\mathrm{EI}_{\mathrm{r}}$ to evoke the same firing rate at the soma. The simulations were run for $400 \mathrm{~s}$; the total current of all the synaptic and dendritic channels was recorded every $0.1 \mathrm{~ms}$; and were implemented in a pre-release version of GENESIS 3 (http://www. genesis-sim.org/; http://www.cbi.utsa.edu).

We quantified the effects of several $\mathrm{EI}_{\mathrm{r}}$ on the histogram of each dendritic current. We found that only the histograms of the $\mathrm{CaP}\left(\mathrm{I}_{\mathrm{CaP}}\right)$ and $\mathrm{Kc}$ currents $\left(\mathrm{I}_{\mathrm{Kc}}\right)$ varied, while all others remained constant. The source of this variability comes from the synaptic activity and from interactions among channels. We used mutual information (MI) to quantify the information from the total excitatory synaptic current $\left(\mathrm{I}_{\mathrm{Glu}}\right)$ encoded in each dendritic current. In this context, each active current was considered an information channel. $\mathrm{MI}\left(\mathrm{I}_{\mathrm{CaP}}, \mathrm{I}_{\mathrm{Glu}}\right)$ and $\mathrm{MI}\left(\mathrm{I}_{\mathrm{Kc}}\right.$, $\mathrm{I}_{\mathrm{Glu}}$ ) was sensitive to different $\mathrm{EI}_{\mathrm{r}}$ that resulted in the same firing rate at the soma. We quantified the changes in $\mathrm{MI}\left(\mathrm{I}_{\mathrm{CaP}}, \mathrm{I}_{\mathrm{Glu}}\right)$ and $\mathrm{MI}\left(\mathrm{I}_{\mathrm{Kc}}, \mathrm{I}_{\mathrm{Glu}}\right)$ as a function of the

\footnotetext{
* Correspondence: fidel.santamaria@utsa.edu

${ }^{1}$ Biology Department and Neurosciences Institute, University of Texas at San Antonio, San Antonio, TX 78249, USA
}

density of dendritic conductances $\left(\mathrm{g}_{\mathrm{CaP}}\right.$ and $\left.\mathrm{g}_{\mathrm{Kc}}\right)$. This analysis showed that $\mathrm{MI}\left(\mathrm{I}_{\mathrm{CaP}}, \mathrm{I}_{\mathrm{Glu}}\right)$ was less sensitive to changes in $\mathrm{g}_{\mathrm{CaP}}$ than to variations in $\mathrm{g}_{\mathrm{Kc}}$. Thus, the interactions between $\mathrm{I}_{\mathrm{Kc}}$ and $\mathrm{I}_{\mathrm{CaP}}$ are important to regulate information transfer in the dendrite. We extended our analysis to determine $\mathrm{MI}\left(\mathrm{I}_{\mathrm{CaP}}(\mathrm{t})\right.$ or $\left.\mathrm{I}_{\mathrm{Kc}}(\mathrm{t}), \mathrm{I}_{\mathrm{Glu}}(\mathrm{t}-\Delta \mathrm{t})\right)$, for $\Delta \mathrm{t}$ from 0 to $1 \mathrm{~s}$ and as a function of channel density and $E I_{r}$. We found that MI decayed in about $100 \mathrm{~ms}$ as a function of the combination of $g_{\mathrm{CaP}}$ and $\mathrm{g}_{\mathrm{Kc}}$ with the level of synaptic activity, reducing this window to a few milliseconds with high rates of $\mathrm{EI}_{\mathrm{r}}$. Overall, our results show that different dendritic conductances differentially encode synaptic activity and that dendritic excitability and the level of synaptic activity regulate the flow of information in dendrites.

\section{Acknowledgements}

UTSA-TRAC and NSF HRD-0932339.

\section{Author details}

'Biology Department and Neurosciences Institute, University of Texas at San Antonio, San Antonio, TX 78249, USA. ${ }^{2}$ University of Texas Health Science Center at San Antonio, San Antonio, TX 78229, USA.

\section{Published: 20 July 2010}

\section{References}

1. De Schutter E, Bower JM: An active membrane model of the cerebellar Purkinje cell II. Simulation of synaptic responses. J Neurophysiol 1994, 71(1):401-419.

2. Santamaria F, Tripp PG, Bower JM: Feedforward inhibition controls the spread of granule cell-induced Purkinje cell activity in the cerebellar cortex. J Neurophysiol 2007, 97(1):248-263.

doi:10.1186/1471-2202-11-S1-P165

Cite this article as: Coop et al:: Synaptic activity and excitability modulates information transfer in Purkinje cells: a modeling study. BMC Neuroscience 2010 11(Suppl 1):P165. 